\title{
Ivasik Telesik.
}

Nekaj misli ob knjigi Nazarija

Nazarova »Obredni izvor

pravljičnega besedila«*

\section{Vlado Nartnik}

Ukrainian philologist Nazarij Nazarov has researched a popular fairy tale of the East Slavs that is known among the Ukrainians under the name "Ivasik Telesik", among the Belarusians as "Sinek Pilipka", and among the Russians as "Terešečka". Of particular interest are several rhymed verses inserted in the text. Nazarov believes that these inserts primarily dissect the text, thereby creating a ceremonial form. A comparison of this Eastern Slavic tale with four Slovenian poems indicates that the purpose of these inserts may also be to soothe and lull to sleep.

KEYWORDS: Ivasyk-Telesyk, Pilipka the Son, Tereshechka, folktales, formulaic songs, invocation, prototype.

Ukrajinski filolog Nazarij Nazarov je svojo knjižico, ki nosi naslov Obredni izvor pravljičnega besedila: »Telesik« z vidika lingvistike (2015), posvetil priljubljeni pravljici vzhodnih Slovanov, pri Ukrajincih znani kot Ivasik Telesik, pri Belorusih kot Sinek Pilipka, pri Rusih kot Terešečka (Nazarov 2013: 2). Pravljica teče v glavnem takole:

Živela sta mož in žena, ki nista imela otrok. Ko sta se postarala, je žena rekla možu, naj gre v gozd poiskat krepelo, da ji bo namesto otroka. Mož je sprva ugovarjal, nato je čudni želji ustregel. Naredil je zibelko in žena je v njej zibala krepelo, dokler ni zaspala ob pesmi:

\section{Zaspi, zaspi, Telesik moj,}

zasanjaj radostno z menoj!

Ko se je zjutraj zbudila, je v zibelki ležal otrok. Starša sta mu vsa vesela dala ime Ivasik Telesik. Otrok je hitro rasel. Ko je bil že večji, je prosil očeta, naj mu naredi zlat čoln in srebrno veslo, da bo v reki lahko lovil ribe. Tako se je tudi zgodilo. Ivasikje lovil ribe, mati pa je hodila na breg in ga klicala:

\footnotetext{
* Nazarij Nazarov, Obrjadove pohodžennja kazkovogo tekstu: »Telesik« z pogljadu lingvistiki [Назарій Назаров, Обрядове походження казкового тексту: »Телесик« 3 погляду лінгвістики].
} 
Ivasik moj, Telesik moj,

le plovi sem ino postoj,

da jesti, piti ti podam!

Ivasik jo je slišal in slušal. Mati mu je podala jesti, piti ter on njej ribe. Ko je šel naprej lovit, se je kača v grmovju trudila posneti materin klic, da bi ga ujela. Prvič je klicala grobo, drugič tolsto, tretjič tanko in tedaj ji je Ivasik nasedel. Kača ga je ujela in odnesla domov. Hčeri Olenki je naročila, naj zakuri peč in v njej speče Ivasika. Ta se je delal, da ne zna sesti na lopar, zato ga je Olenka učila in sama sedla gor, Ivasik pa jo je hitro porinil naprej ter zaprl peč. Nato se je skril na javor, ki je rasel ob kačji koči.

Kača je medtem zbirala goste. Ko se je z njimi vrnila, je v peči našla pečenko. Posedli so za mizo in se pogostili z njo. Ivasik pa se je oglasil z javora in razkril, da se niso mastili z njim, ampak z Olenko. Kača z gosti se je zagrizla v javor, da bi ga podrla. Ivasik je prestrašen začel klicati gosi, ki so v jatah letele nad javorom:

Gosi velike, majcene,

na krila posadite me,

$k$ očetu ponesite me.

Tam jesti ino piti bo,

bogato godovati bo.

Javor je preletela prva jata in druga in tretja in šele samcat gosaček ga je zadnji hip rešil in odnesel domov $k$ očetu in materi.

V pravljici je posebej zanimivih po nekaj rimanih vrstic v obliki zvalnega poziva, velelne prošnje ter povednega obeta (Nazarov 2015: 23). Osip Bodjanski jih je zabeležil že leta 1835 in v smislu privrnitve petega prabesedila prepesnil kar celo pravljico. Nazarov pa meni, da rimani vložki predvsem členijo besedilo in s tem vzpostavljajo obredno gradnjo, primerljivo zlasti z belorusko igro Kuščar (Nazarov 2015: 15 in 36). Pravljična kača poje najprej grobo in tolsto, medtem ko Telesikova mati tanko. Zato njen otrok ve, da je to res njegova mati. Tako petje je vzporedno petju sibirskih šamanov, kjer predstavniki spodnjega sveta pojejo $\mathrm{z}$ basom ter srednjega sveta $\mathrm{z}$ naravnim glasom. Zaporedje treh vložkov A - B - C se nekako vpenja med štiri slovenske pesmi takole:

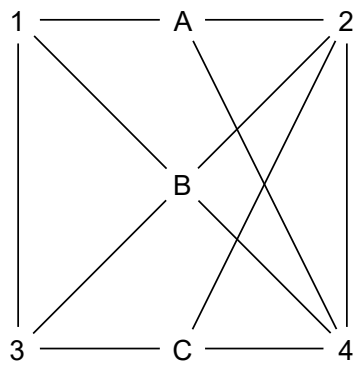


Rimani vložek A se nanaša na krepelo kot nadomestek otroka v zibelki. Blizu mu je klada, ki skriva dete na začetku slovenske legende Kruta mati (Štrekelj 1898: 245 in 246):

Izidor ovčice pasel,

ko je majhen fantič bil,

in jih je do nje pripasel,

do te klade pirave.

Izpod klade dete stopi:

»Vi ste pravi ujec moj."

»Kak bi jaz bil ujec tebi,

ko imam eno sestro,

pa še tista dnes moži se,

še zeleni venec ma."

Izidor domov požene,

malo dete spremlja ga.

Malo dete v hišo stopi

in pozdravi svate vse:

"Jaz pozdravim vas vse svate,

svoje matere pa ne!"

In so ga izprašovali:

"Kdo bi tvoja mati bli?"

"Moja mati so pa tista,

ki zeleni venec ma."

»Če sem bla kdaj tvoja mati,

naj mi venec zagori!«

Komaj to izgovorila,

ji je venec zagorel.

»Niste meli samo mene,

saj ste meli troje nas.

Enga vergli ste v morje,

da se je potopil bil.

Drugga vergli ste med svinje,

da so ga raztergale.

Mene djali ste pod klado,

pod to klado piravo.

Hladni dežek me je kopal,

topli vetri zibali,

me Marija povijala,

sveti Janez kerščoval.»

Legenda po svoje prekriva spopade v družini egiptovskih bogov. Set, zavistni sin boga zemlje Geba in boginje neba Nut, je dal svojega brata Ozirisa zapreti v skrinjo in ga spustiti po reki navzdol proti morju, dokler ni skrinje našla Ozirisova sestra in hkrati žena 
Izida. Ko je Set na skrito skrinjo spet naletel, je Ozirisovo truplo razkosal in ga raztrosil po Egiptu (Cavendish - Ling 1988: 106). Novost legende je v tem, da Izidorjev tretji nečak, ki spominja še na Ozirisovega sina Horusa, pod klado čudežno preživi po zaslugi Marije in svetega Janeza, pravzaprav Ivasikovega soimenjaka (Petrovskij 1966: 118).

Rimani vložek B je v zvezi z dogajanjem ob vodi, primerljivo s prejšnjo legendo pa preživetje vsaj enega pastorka beleži slovenska balada Rožlin in Verjanko (Grafenauer 1973: 62 in 63):

»Kak hoče bit? Kaj hočva strit?

Ti si premlad še za ženit,

jaz sem prestara za možit."

»Le, mati, omožite se,

vzemite, kogar hočete;

le hudega Rožlina ne,

ki velik moj sovražnik je;

je bratca in očeta vbil

in komaj sem mu jaz ušel.»

Al mati nič ni marala,

Rožlina vzela hudega,

Verjankovga sovražnika.

Zvečer z njim grede v kamro spat;

Verjanko gre pod okno stat.

Je v kamri govorila mat:

»O, škoda, škoda za blago,

ko zdaj se razdelilo bo!

Kaj pravim tebi, ljubi mož, tam v černi gori, v temni goš

pod bukvijo vir videl boš.

Ti rečem se za bukev skrit,

Verjanka tam skrivaj vmorit:

se jutri bolno bom storila

in h sinu rekla, govorila,

da boljši meni pred ne bo, da pila merzlo bom vodo, ki v černi gori se dobo.

Sin me je vbogal vselej rad, tja h viru hočem ga poslat." Pretiho gre Verjanko stran, besede njene v serc ohran.
Ko je prišel spet beli dan,

Verjanko h mater v kamro gre

in reče ji besede te:

»Kaj pravim, ljuba mati vi,

visoko sonce že stoji,

to vaša scer navada ni,

da bi tak dolgo v postlji bli!«

»Sin ljubi, bolna sem hudo,

oh, boljši meni pred ne bo,

da pila merzlo bom vodo,

ki v černi gori se dobo."

Sin vzel je v roke kanglico,

pripasal si je sabljico,

je djal na ramo pušico,

po vodo šel pod bukvico.

»Kaj jemlješ ti orožje, sin?

Saj v černi gori ni zverin,

$z$ dežele zbežal je Turčin."

»Peruti ptičica ima,

plavuti ribica ima,

junak z orožjom se obda."

Verjanko gre pod bukvico,

v Rožlina sproži pušico,

odpre mu žile z sabljico

in $v$ svojo belo kanglico

natoči vroče si kervi,

$z$ njo h materi domov hiti,

besede take govori:

"Želeli piti sinovo,

zdaj nate kri Rožlinovo! « 
Rimani vložek C kaže na rešitev v pticah. Verjanko pri tem ustreza Orestu v grški bajki Orest in Elektra. Orestu namreč pomaga tudi sestra Elektra podobno kakor deklica svojemu bratu v Župančičevi pesmi Kanglica (Drolc 1970: 20):

Deklica šla je po vodo

z lepo srebrno kanglico.

Zora na nebu sevala,

ptičica v logu pevala.

Jagoda zrela nudi se:

»Daj, le za hip pomudi se!"

„Jagoda rdečka, dober dan!

Ali moj bratec je bolan

in ozdravil prej ne bo,

da mu prinesem z vrelca vodo,

deklica moram zajeti jo,

preden še sonce obsveti jo ..."

Hladne vodice zajela je,

bistro domov odhitela je.

Deklica šla je po vodo

z lepo srebrno kanglico,

deklica je domov prišla,

kanglica bila zlata vsa.

Umetna pesem Kanglica pa je dala še podlago ljudski pesmi Radoživa ribica (Nazarov 2015: 38), s tem da se deklica ni skrajšala v deklo, ampak je zanihala med dekletom na slovenskem jugu (Merhar 1978: 170 in 172) ter deklino na severovzhodu (Terseglav 1989: 68) in dečvo na severozahodu (Štrekelj 1903: 239 in 530):

Dečva je po vodo šla pod visoko planino, vodo je zajemala, je ribico zajela.

Ribica prosila je: »Oj pusti me živeti, rada bi še plavala in se z vodo igrala.«
Vabilo je jabolko, to jabolko rudeče, dečva ga je vtergala, ga svojmu fantu dala:

»Ti boš tesal zibelko

iz javorovga lesa, notri se bo zibal sin iz najinga telesa."

Dečva bla je vsmiljena,

je ribico spustila, ribica je splavala, je dečvo oškropila. 
Primerjava zadnjih dveh pesmi kaže, kako je brata zamenjal fant, ptičico ribica, jagodo jabolko, kanglico zibelka (Nazarov 2015: 40). Ob soočenju vzhodnoslovanske pravljice z vsemi štirimi slovenskimi pesmimi pa rimani vložki kažejo tudi na vlogo pomirjanja in uspavanja. Po karelskem izročilu naj bi večerno pravljenje pravljice ustvarjalo železen obroč, ki varuje hišo do jutranjega ugibanja ugank (Lavonen 1982: 5).

\section{VIRI IN LITERATURA}

Cavendish, Richard, Trevor O. Ling, 1988, Mitologija. Ljubljana: Mladinska knjiga.

Drolc, Franc 1970, Slovenski jezik. Zagreb: Školska knjiga.

Grafenauer, Ivan, 1973, Kratka zgodovina starejšega slovenskega slovstva. Celje: Mohorjeva družba v Celju.

Lavonen, Nina A., 1982, Karel'skie narodnye zagadki. Petrozavodsk: Karelija.

Merhar, Boris, 1978, Mlada Breda. Ljubljana: Mladinska knjiga.

Назаров, Назарий, 2015, Обрядове походження казкого тексту: »Телесык« з погляду лінгвистыкы. Кыйив - Умань: ФОП Жовтый О.О.

[Nazarov, Nazarij, 2015, Obrjadove pohodžennja kazkogo tekstu: »Telesyk« z pogljadu lingvistyky. Kyjiv - Uman': FOP Žovtyj O.O.]

Petrovskij, Nikandr A., 1966, Slovar' russkih ličnyh imen. Moskva: Sovetskaja Enciklopedija.

Štrekelj, Karel, 1898, Slovenske narodne pesmi I. Ljubljana: Slovenska matica.

Štrekelj, Karel, 1903, Slovenske narodne pesmi II. Ljubljana: Slovenska matica.

Terseglav, Marko, 1989, Porabska pesmarica. Budimpešta: Tankönyvkiadó. 


\section{IVASIK TELESIK. REFLECTIONS ON THE BOOK “THE RITUAL ORIGIN OF A FAIRY TALETEXT” BY NAZARIJ NAZAROV \\ VLADO NARTNIK \\ $\infty \infty$}

Ukrainian philologist Nazarij Nazarov has focused his book titled "The Ritual Origin of a Fairy Tale Text" [Obrjadove pohodžennja kazkogo tekstu. "Telesyk" z pogljadu lingvistyky 2015] on a popular East Slavic fairy tale, which in Ukraine is known as Ivasik Telesik, among the Belarusians as Sinek Pilipka, and among the Russian as Terešečka. The fairy tale is especially interesting because of several sets of rhymed verses, inserted in the text, in the form of an imperative, an appeal, and praise. Osip Bodjanski recorded them on paper as early as 1835, and reworked the entire fairy tale in the form of a sung prototext. Nazarov, however, believes that these rhymed inserts primarily dissect the text, thereby forming a ceremonial form comparable in particular to the Belarusian game Lizard. In some way, the sequence of the three inserts $\mathrm{A}-\mathrm{B}-\mathrm{C}$ can be found in four Slovenian poems as well:

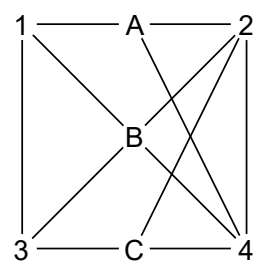

The rhymed insert A refers to a cudgel placed as a surrogate child in a cradle. This resembles the clog hiding a baby at the beginning of the Slovenian legend Kruta mati (Cruel Mother). The insert B is connected with events taking place near water. In comparison with the above-mentioned legend, the Slovenian ballad Rožlin in Verjanko (Rožlin and Verjanko) mentions the survival of at least one stepson. The insert $\mathrm{C}$ indicates rescue with the help of birds. In this case, Verjanko corresponds to the Greek Orestes in the Greek belief tale Orestes and Electra. Orestes namely survives with the help of his sister Electra, a motif similar to the one in the poem Kanglica (Pail) by Oton Župančič. This literary poem served as a basis for the folk song Radoživa ribica (The Merry Little Fish). A comparison of both shows that the brother was replaced by the boy; the bird by the fish; the berry by the apple; and the pail by the cradle. A comparison of this Eastern Slavic tale with four Slovenian poems indicates that the purpose of these rhymed inserts may also be to soothe and lull to sleep. 